ISSN1027-5495. Functional Materials, 24, No.3 (2017), p. 490-495

doi:https://doi.org/10.15407/fm24.03.490

(C) 2017 - STC "Institute for Single Crystals"

\title{
Research on game scheduling of galvanizing pipe production
}

\author{
Yingying Li, Shaohua Dong \\ School of Mechanical Engineering, University of Science and Technology \\ Beijing, Beijing 100083, P.R. China
}

Received December 20,2016

\begin{abstract}
In this paper, we analyze and integrate the production process of "hot-dip galvanized steel pipe", the main product in the case enterprise and builds a model for the production scheduling with Cooperative Game Theory from the perspective of the enterprise. In order to get the Optimal Game Scheduling Solution, Genetic algorithm is used and Shaply value thought and 8 rule allocation method are combined to solve the problem of increased profit allocation in different customers. And fair and reasonable allocation mechanism is of great significance to the stability of the coalition and enterprise development.
\end{abstract}

Keywords: Galvanizing Pipe Production, Cooperative Game Theory, Genetic algorithm.

Проанализирован процесс производства горячеоцинкованных стальных труб, основного продукта предприятия, построена модель планирования производства при помощи кооперативной теории игр с точки зрения предприятия. Чтобы получить оптимальное решение используется генетический алгоритм. Метод построения значений Shaply и метод распределения правил В объединяются для решения проблемы увеличения распределения прибыли у разных клиентов, что имеет большое значение для стабильности развития предприятий.

\section{Дослідження питань виробництва гальванічних труб Yingying Li, Shaohua Dong}

Проаналізовано процес виробництва гарячеоцинкованим сталевих труб, основного продукту підприемства, побудована модель планування виробництва за допомогою кооперативної теорії ігор з точки зору підприемства. Щоб отримати оптимальне рішення використовуеться генетичний алгоритм. Метод побудови значень Shaply i метод розподілу правил $B$ об'єднуються для вирішення проблеми збільшення розподілу прибутку у різних кліентів, що має велике значення для стабільності розвитку підприемств.

\section{Introduction}

The concept of computer integrated manufacturing system (CIMS) is put forward by Dr. Joseph Harrington firstly in 1973. Production scheduling technology is one of key and core technologies of CIMS [1]. Production scheduling has been widely concerned because of its important place in enterprise production management in recent decades. Experts and scholars in the field of production scheduling have proposed a series of research methods to solve all kinds of production scheduling problems.
Such as some traditional scheduling methods (e.g. mechanical optimization method, simulation method) and intelligent scheduling methods (e.g. genetic algorithm, swarm intelligence algorithm, neural network algorithm). These methods have achieved good results in the field of production management, and have made contributions to raising the level of production management. The Game Theory proposed and developed in the middle of 20 th century is mainly used to solve the problem of interests balance between enterprises and customers and among multiple customers. Meanwhile, the production 
scheduling is a typical problem of resource allocation and competition with constraints and optimization index requirements where there are a lot of conflicts among customers, customers and enterprises. Therefore Game Theory has become a good tool to describe the scheduling problem. The game is generally divided into non-cooperative game and cooperative game. Non-cooperative game highlights the concept of individual competition, emphasizing the individual rationality, while in the cooperative game, the agents can reach a binding agreement to carry out a coalition. Cooperative game embodies the spirit of teamwork, emphasizing the collective rationality.

Tijs (1986) used the cooperative game theory to solve the problem of cost saving in production scheduling, and proposed the cost difference allocation method based on $\tau$ value in the scheduling problem[2]. Curiel et al. (1989) started a line of research that investigates the interaction between sequencing situations and cooperative games. They considered the class of one-machine sequencing situations in which no restrictions like due dates and ready times are imposed on the jobs and the weighted completion time was chosen as the cost criterion [3]. Zhou (2012) allocated saving costs reasonably by cooperation theory in the game of one-machine scheduling with due-date and tardiness penalty[4].

In the literature review of the game scheduling problems are standing in the customers' point of view, however in this paper, the production process of a steel pipe enterprise's main product "Hot dip galvanized steel pipe" is as an example to study, in which we analyze the contribution of customers to increasing the profit of the case enterprise with cooperative game theory to help to adjust customer strategy accordingly.

\section{Cooperative game model of galva- nizing pipe production}

The galvanizing process is classified and integrated in consideration of the actual situation in the enterprise. Integrated galvanizing process is displayed in Table 1. Taking full account of the properties of the works, the inte- grated galvanizing process is considered as a single machine model. Before modeling, the assumptions are as follows:

1. Adequate supply of raw materials is assured;

2. Customers' payment of accepting the coalition is not more than the payment of rejecting the coalition;

3. Each galvanizing task belongs to only one customer;

4. Galvanizing tasks arrive at the same time. There is no waiting time;

5 . The enterprise provides an initial scheduling order before the beginning of galvanizing with a view to the due dates and the weight of the customers. Under the initial order, once the delivery time of one task exceeds the due date, the task will be rejected, and the profit that this task brings to the enterprise is 0 simultaneously;

6. If one customer accepts the coalition, the delivery time of each task of this customer in the coalition is allowed to be later than the due date, but not later than the deadline. If not, the profit of the task is 0 ;

7. The machine can only carry out one task at the same time. The task can be neither stopped early nor preempted by other tasks;

8. The time of starting galvanizing is 0 .

Based on the above assumptions, the mathematical model of galvanizing production scheduling problem is given. The problem can be described as an eight tuple $\left(N, l, T, R, \sigma_{0}, E D, L D, F\right) . N$ represents the set of galvanizing tasks, in which galvanizing tasks are called agents.. $l$, the machine set, is set to 1 in the model. $R$ is defined as galvanizing time set. $\sigma_{0}$, a sort of $N$ is seen as initial scheduling order from the enterprise. $E D$ and $L D$ are due-dates set and deadlines set, respectively. $F(i)$ is to be interpreted as the penalty function when the delivery time of $i$-th task is between $E D(i)$ and $L D(i)$. According to the customers' orders, the profit that the enterprise get from productions and sales is defined as follows:

$$
\begin{gathered}
U^{\prime}=\sum R_{i} \\
R_{i}=q_{i} \times\left(p_{i}-c_{i}\right)-F_{i}
\end{gathered}
$$

Table 1. Integrated Galvanizing Process

\begin{tabular}{|c|c|c|}
\hline Serial Number & Process Name & Process Description \\
\hline 1 & Pickling & Picking, washing and drying pipes \\
\hline 2 & Galvanizing & Galvanizing the pipes in zinc liquid \\
\hline 3 & Passivation & $\begin{array}{c}\text { Drying the galvanized pipes and spreading the passivator } \\
\text { on the pipe surface }\end{array}$ \\
\hline
\end{tabular}


Table 2. Example Order Information

\begin{tabular}{|c|c|c|c|c|c|c|c|c|}
\hline $\begin{array}{c}\text { Task } \\
\text { Num- } \\
\text { ber }\end{array}$ & $\begin{array}{c}\text { Cus- } \\
\text { tomer } \\
\text { Number }\end{array}$ & Specifications & Weight, t & $\begin{array}{c}\text { Unit Cost, } \\
\text { Yuan/t }\end{array}$ & $\begin{array}{c}\text { Unit Price, } \\
\text { Yuan/t }\end{array}$ & $\begin{array}{c}\text { Due- date, } \\
\mathrm{h}\end{array}$ & $\begin{array}{c}\text { Deadline, } \\
\mathrm{h}\end{array}$ & $\begin{array}{c}\text { Penalty Cost, } \\
\text { Yuan/h }\end{array}$ \\
\hline 1 & 1 & $114.0 \times 3.75 \times 6.0$ & 341.73 & 2894.87 & 2965.90 & 103.80 & 186.84 & 122.06 \\
\hline 2 & 1 & $140.0 \times 4.0 \times 6.0$ & 33.73 & 2944.36 & 3188.00 & 98.95 & 148.43 & 21.73 \\
\hline 3 & 1 & $26.3 \times 2.5 \times 6.0$ & 38.25 & 2866.56 & 3502.39 & 54.75 & 87.60 & 40.79 \\
\hline 4 & 2 & $33.5 \times 3.25 \times 6.0$ & 27.52 & 2758.90 & 3290.02 & 52.64 & 73.69 & 43.01 \\
\hline 5 & 2 & $42.0 \times 2.75 \times 6.0$ & 120.81 & 2851.03 & 3323.17 & 89.71 & 116.63 & 149.17 \\
\hline 6 & 2 & $42.0 \times 3.0 \times 6.0$ & 139.90 & 2673.58 & 3278.43 & 102.32 & 133.02 & 149.41 \\
\hline 7 & 2 & $47.0 \times 2.5 \times 6.0$ & 26.16 & 2854.97 & 3332.50 & 85.89 & 154.61 & 12.69 \\
\hline 8 & 3 & $47.5 \times 3.0 \times 6.0$ & 117.60 & 2752.20 & 3258.46 & 86.65 & 155.98 & 55.28 \\
\hline 9 & 3 & $47.5 \times 3.25 \times 6.0$ & 46.73 & 2841.91 & 3213.75 & 97.57 & 175.62 & 19.24 \\
\hline 10 & 4 & $75.0 \times 3.0 \times 6.0$ & 24.83 & 3029.24 & 3060.01 & 87.33 & 157.19 & 10.88 \\
\hline 11 & 4 & $75.0 \times 3.25 \times 6.0$ & 85.54 & 2950.75 & 3000.58 & 91.32 & 164.37 & 35.13 \\
\hline 12 & 4 & $75.0 \times 3.5 \times 6.0$ & 118.79 & 2859.98 & 2969.51 & 93.80 & 150.08 & 62.67 \\
\hline 13 & 4 & $114.0 \times 3.25 \times 6.0$ & 45.54 & 3002.84 & 3041.34 & 84.19 & 115.91 & 43.66 \\
\hline 14 & 5 & $114.0 \times 3.5 \times 6.0$ & 331.63 & 2958.61 & 2994.19 & 128.28 & 177.57 & 201.44 \\
\hline
\end{tabular}

$$
F_{i}=f_{i} \times\left(T_{i}-E D_{i}\right)
$$

where for all $i \in N, p_{i}, c_{i}, q_{i}$ and $f_{i}$ are represented the unit price, the quantity, the penalty of $i$-th specification galvanized pipe respectively. Given the initial order $\sigma_{0}$, we have the initial profit of the enterprise:

$$
\begin{aligned}
& U_{0}=\sum q_{i}^{\prime} \times\left(p_{i}-c_{i}\right) \\
& q_{i}^{\prime}=\left\{\begin{array}{l}
q_{i}, T_{i}-E D_{i} \leq 0 \\
0, T_{i}-E D_{i}>0
\end{array}\right.
\end{aligned}
$$

where if the delivery time of $\mathrm{i}$-th task exceeds the due date, the quantity $q_{i}^{\prime}$ is 0 , otherwise is $q_{i}$. In the cooperative gaming, the increased profit after re-order is given:

$$
U=\max \left(U^{\prime}-U_{0}\right)
$$

The ultimate goal of the cooperative game model in this paper is to maximize the increased value of enterprise profit. Since the enterprise profits under the initial order $\sigma_{0}$ can be calculated, the goal of cooperative game model is transformed into maximizing the value of $U^{\prime}$. When satisfying the following constraints and making $U^{\prime} \max$, the scheduling solution is called the optimal game scheduling solution for the galvanized production in this model:

$$
T_{i}-L D_{i} \leq 0, i=1,2, \cdots, n
$$

The profit each task contributes in the coalition will be analyzed in detail in section 4 . Heuristic genetic algorithm will be used to solve the cooperative game model in the next section for improving convergence speed.

\section{Solving the cooperative game model of galvanizing pipe production}

The previous section we introduced the problem of galvanizing production scheduling and used the cooperative game theory to establish a cooperative game scheduling model based on the maximization of enterprise's profit. In this section we will use the genetic algorithm to solve the model, and provide method support for the allocation of profit in the next section. The genetic algorithm flow is as follows:

(1) Coding design

Firstly, the model is coded according to the following rule: the Galvanizing tasks of $n$ specifications are sequential encoded from 1 to $n$ under the initial order of $\sigma_{0}$.A chromosome containing $n$ genes is obtained.

(2) Fitness function design

The goal of the cooperative game model established in the previous section is to maximize the profit of the enterprise. Therefore, the maximum $U_{\max }^{\prime g}$ and minimum $U_{\min }^{\prime g}$ are selected in the $g$-th generation to compose the fitness function:

$$
\text { fitness }(i)=\left(\frac{U_{i}^{\prime g}-U_{\min }^{\prime g}}{U_{\max }^{\prime g}-U_{\min }^{\prime g}+0.001}\right)^{c}
$$

where $U_{i}^{\prime g}$ is the enterprise's profit under the $i$ order in the $g$-th generation, and $c$ is the normalized phase-out acceleration index. 


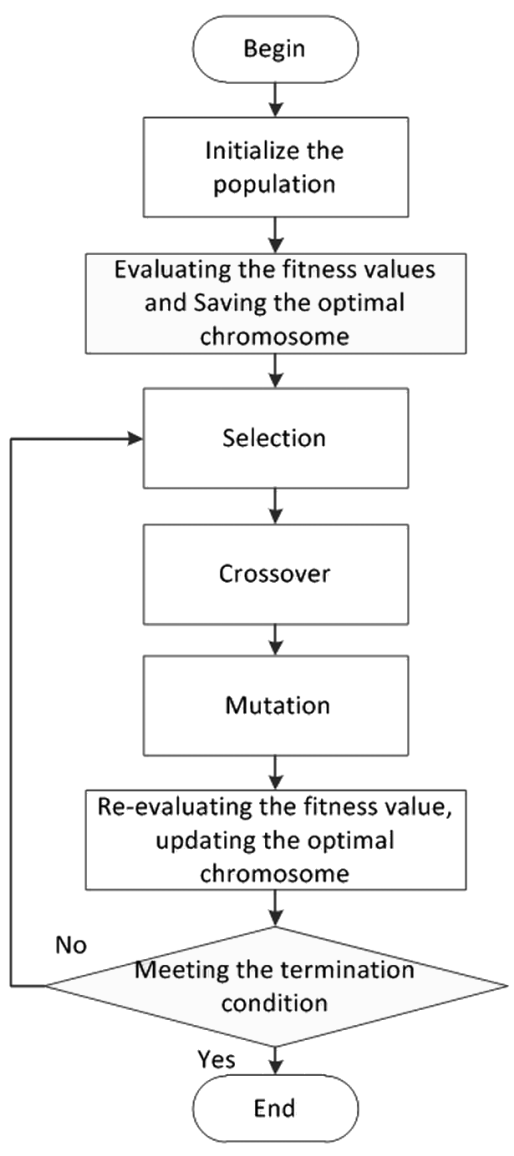

Fig. 1. Genetic algorithm flow chart

(3) Selection, Crossover and Mutation Operator

The roulette method is chosen to generate the selection operator. The crossover operator uses a single point of crossover. The mutation operator is obtained by comparing the random probability with the mutation probability $P_{m}$ .When the random probability is less than $P_{m}$ , the random number method is used to generate a task number to replace the existing task number of the gene.

(4) Algorithm Flow

Based on the above analysis of significant steps of genetic algorithm, the genetic algorithm flow is given in Fig.1.

In order to verify the rationality and correctness of the galvanization cooperative game model in the previous section and the solution designed in this section, in this paper, we use Matlab software to simulate the experiment. In the experiment, we integrate multiple production lines into a production line in the galvanizing workshop, and 14 kinds of specifications need to be galvanized after integrating and classifying the customer orders. Table 2 shows the example order information. The experimental parameters are set as follows: the

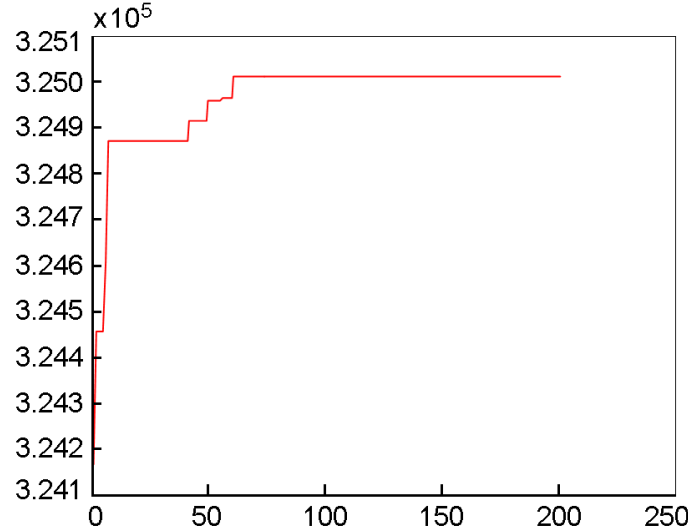

Fig. 2. Genetic algorithm simulation convergence curve

population is 100 , the number of generations is 200 , normalized phase-out acceleration index is set to be 2 , crossover probability is 0.75 and the mutation probability is 0.2 .

According to the above genetic algorithm parameters settings and order information, genetic algorithm simulation convergence curve is shown in Fig. 2. With the combination of the maximum profit of the enterprise $U^{\prime}=325009.50$ and the profit in the initial scheduling order $U_{0}=254753.60$, the increase of enterprise profit is $U=70255.90$ and rises $27.6 \%$.

It can be seen from the simulation results that the profit from the optimized production scheduling order is considerably higher than from the initial order. As the promotion of profit is based on the customer coalition, it is important to study which customers join in the coalition and the contribution of each customer in the coalition for adjusting the customer relationship management strategy. In the next section, we will focus on the analysis of the coalition's profit allocation.

\section{Galvanized production game coali- tion profit allocation}

After obtaining the optimal scheduling solution of the cooperative game model, it is necessary to allocate the profit rationally. A reasonable allocation mechanism is of great significance to the stability of the coalition. All of the contributors in the coalition can benefit from the allocation. The profit allocation mechanism should apply the following rules:

(1) Collective Principle

Under the optimal cooperative game scheduling $\sigma_{b}$ the total profit is not less than the total profit under other scheduling, that is, the optimal cooperative game scheduling solution can maximize the profit. Meanwhile, the profit margin must be fully allocated among all of the participating agents, and there is no surplus. 


\section{(2) Individual Rationality Principle}

The cost savings of the customer after joining the coalition must be nonnegative, which is the prerequisite for the formation of the coalition. And the relevant assumptions have been made in the cooperative game model in this paper.

(3) No Damage Principle

When the customers in the coalition is part of the all customers, the interests of non-affiliated customers can't be damaged.

(4) Fairness Principle

The fairness and reasonability are reflected in the following the allocation strategy: The more contribution the customers make, the more profit they should be allocated, and the customer who makes no contribution can't participate in the allocation of profits.

According to the above principles and the situation of the enterprise, this paper will introduce two kinds of key cooperative game allocation methods: Shapley value method and $\beta$ rule allocation method.

(1) Shapley Value

The Shapley value proposed by Shapley in 1953 solved the allocation in the cooperative game reasonably and fairly. The status of Sharply value in cooperative game is equivalent to the status of Nash equilibrium in noncooperative game. The main ideas of Sharply value are described as follows:

It is assumed that agents in the cooperative game can form a perfect coalition, and the number order of agents in the game is $(1,2, \ldots, n)$, we get:

$$
\begin{gathered}
x_{1}=v(\{1\}) \\
x_{2}=v(\{1,2\})-v(\{1\}) \\
x_{3}=v(\{1,2,3\})-v(\{1,2\}) \\
\vdots \\
x_{n}=v(\{N\})-v(N,\{n\})
\end{gathered}
$$

It leads to an allocation of $x=\left(x_{1}, x_{2}, \cdots, x_{n}\right)$, which is related to the number of agents in the coalition. Reassigning the number of the agents in the coalition, we will receive another allocation under this numbering. With any numbering mode, the income of each agent can be obtained by getting the difference between the income of the coalition after the agent joined and before he joined. And the number of numbering modes is $n$ ! in a coalition with $n$ agents. Therefore, when defining the coalition after agent $i$ joined as $M \cup\{i\}$, the income $\varphi_{i}(v)$ that $i$ should be allocated is the average of incomes he got in $n$ ! allocations [5]: $\varphi_{i}(v)=$

$\sum_{M \subset N-\{i\}} \frac{|M| !(|N|-|M|-1) !}{|N| !}[v(M \cup\{i\})-v(M)]$

$\varphi_{i}(v)=\sum_{M \subset N-\{i\}} W(M)[v(M \cup\{i\})-v(M)]$

(2) $\beta$ rule allocation method

The $\beta$ rule allocation method is a allocation method proposed by Curiel[3] in studying sequence game. Above all, we define several sets about order $\sigma_{0}$ :

$P\left(\sigma_{\theta}, i\right)$ : the set of agents in front of $i$

$P\left(\sigma_{0}, i\right)$ : the set of agents in front of $i$ adding $i$

$F\left(\sigma_{0}, i\right)$ : the set of agents behind of $i$

$F\left(\sigma_{0}, i\right)$ : the set of agents behind of $i$ adding $i$

The income of $i$-th agent is derived from the following formula:

$$
\begin{aligned}
& \beta_{i}(v)= \\
& =\frac{1}{2}\left[\overline{P\left(\sigma_{0}, i\right)}-P\left(\sigma_{0}, i\right)+\overline{F\left(\sigma_{0}, i\right)}-F\left(\sigma_{0}, i\right)\right]
\end{aligned}
$$

It can be seen from the above formula that the income obtained by each agent $i$ is the average of the marginal revenue value obtained by adding $i$ to the coalition in front of $i$ and adding to the coalition behind $i$.

Weighted marginal cost allocate rule on predecessors and followers (WMCA), the allocation method combined by above two methods, is used in this paper and defined as follows:

$$
\begin{gathered}
\beta_{i}(v)=\lambda\left[\overline{P\left(\sigma_{0}, i\right)}-P\left(\sigma_{0}, i\right)\right]+ \\
\quad+(1-\lambda)\left[\overline{F\left(\sigma_{0}, i\right)}-F\left(\sigma_{0}, i\right)\right]
\end{gathered}
$$

where $\lambda$ is the weighting coefficient, and $\lambda \in[0,1]$. The value of $\lambda$ reflects the urgency of the agent's request for advance processing.

In the previous section, the total profit of the enterprise under the initial order and the optimal game scheduling order based on Table 2 have been obtained. Since the different galvanizing tasks belong to different customers, the total contribution of each customer is the sum of the contributions of the customer's galvanizing tasks. The profit the enterprise get from all of the connected task coalitions are shown in Table 3.

In the light of the Formula(12), Table 4 displayed the contributions of different galvanizing tasks by taking the $\lambda=0.6$. From the results of the allocation, we can see from the results of the allocation that the tasks numbered 2,3,4,5 have no contribution to the promotion of profit, which implies the change of processing order of this four tasks has no effect on the profit pro- 
motion. And this statement is confirmed in the reality of that there is no change of the order of this 4 tasks in optimal game scheduling order $[13,2,3,4,5,7,12,11,10,8,6,14,9,1]$.

The total sum of customers' contributions is 70255.90 Yuan, that is, all of the profit allocation is completed.

\section{Conclusions}

In this paper, we take the production process of the main product "hot-dip galvanized steel pipe" in the case enterprise as a research object and analyze the contribution of each customer to the improvement of the enterprise profit with cooperative game theory, which is of great significance to the stability of the coalition and the development of the enterprise. For the tasks of non-expired, their contributed profit can be all owned by the enterprise, while for the tasks of overdue, the enterprise can make compensation for the corresponding customers, which help the enterprise retain customers in the environment with steel-making overcapacity currently.

\section{References}

1. Weiss, Gideon, Michael Pinedo, Interfaces, 25, 130, 1995.

2. Tijs S H and Driessen T S H, Manag. Scien., 32, $1015,1986$.

3. Curiel I, Pederzoli G, Tijs S, Eur. J.Oper.Res, 40, 344, 1989.

4. Zhou Y P, Gu X S,, CIESC J.,61, 1983, 2010.

5. Hongkuan Ma, Game theory. Shanghai: Tongji University press, pp. 152-161, 2015.

6. Gupta M, Mohanty B K, Comp. Industr. Eng., 87, 454, 2015.

7. Feldmann $\mathrm{M}$ and Biskup D, Comp. Industr.Eng., 44, 307, 2003.

8. Hamers H, Klijn F and Suijs J,, Eur. J. Oper. Res, 119, 678, 1999.

9. Borm P, Fiestras-Janeiro G, Hamers H, et al, , Eur. J.Oper.Res., 136, 616, 2002.

10. Gerichhausen M, Hamers H. Partitioning, Eur. J. Oper.Res, 196, 207, 2009.

11. Van Velzen B, Eur. J.Oper.Res, 172, 64, 2006. 